\title{
Ownership And Firm Performance: The Experience Of Saudi Arabia's Emerging Economy
}

Abuzar M. A. Eljelly, Capital Market Authority, Saudi Arabia

\begin{abstract}
This study examines the relationship between firm ownership and corporate performance in Saudi Arabia, using a sample of Listed Private Companies (LPCS) and Listed Government Related Companies (LGRCs). The study compares the operating and market performance of the LPCs and LGRCs during the period 2000-2003 and found that, in general, LGRCs outperform or match the performance of LPCs. More specifically, the study finds that LGRCs tend to mostly outperform LPCs in terms of profitability, as measured by Return on equity (ROE) and Net Profit Margin $(N P M)$, operating efficiently, as measured in terms of Return on assets (ROA), and match them in their stock market risk adjusted performance. The study concludes that these results may have implications for the issue of privatization programs which the government has recently started.
\end{abstract}

Keywords: Saudii Arabia, firm performance, emerging economy, publicly owned, privately owned

\section{INTRODUCTION}

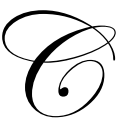

ompanies wholly or partially owned by the government in Saudi Arabia have a strong influence and significant presence in the Saudi Arabian corporate sector. People in Saudi Arabia, including many academics, professionals, and businessmen have frequently called for the government to fully privatize those entities, and a few of them seem to be satisfied with a temporarily significant reduction of government ownership. In a survey conducted by Al-Sarhan and Persley (2001), it was found that 91 percent of businessmen surveyed support privatizing state-owned enterprises.

These views have been driven mainly by the deep rooted belief in the Middle East and elsewhere, as a matter of fact, that government entities are crippled with inefficiencies and waste of resources and that they may do better if placed under the private ownership or under some form of contractual management.

However, those types of arguments, I belief, may not hold in the case of Saudi Arabia for two reasons. First, it should be noted that economic development in Saudi Arabia and in the wider Gulf region, has been pioneered and led by government wholly or partially-owned corporations. Main among these are the oil and gas companies, such as, the petrochemical giant Saudi Arabian Basic Industries Company (SABIC) and the Saudi Arabian Oil Company (ARAMCO), the world largest oil company, as well as other successful companies in other economic sectors. Those pioneered companies have accumulated a solid technical and management experience and had first hand exposure and working relations with foreign companies and business parties in the developed world. In the period that followed oil discovery in Saudi Arabia, the government assumed a proactive entrepreneurial role by establishing state enterprises in key sectors such as oil and gas, transport, marine services, and basic industries. The private sector was almost completely engrossed in trading activities and some lightweight industries. Second, In the case of Saudi Arabia, it can be argued that the state fully- or partially-owned corporations have been genuine profit-oriented entities, and they compete with their private counterparts in various economic sectors, and many of them have been partially privatized and listed on the local stock exchange, Tadawul . Al-Barrak and Al-Harran (2007) argued that in Saudi Arabia competitive market forces are the most important in determining the level of efficiency not the form of ownership of the organization. Their study reached a conclusion that privatization is one 
and not necessarily the best driver of efficiency of the state - owned enterprises in Saudi Arabia. Such view is supported by similar studies carried out within the region such as the one by Dawley and Haidar (2008) which investigated the impact of privatization on value creation in State - owned enterprises in the Middle East and North Africa (MENA) region. The study found that success of privatizing state-owned enterprises needs to coincide with strong reform policies and clear financial and managerial strategies.

Thus, the purpose of this study is to investigate the differences in operating and market performance between the Saudi Listed Private Companies (LPCs) and the Saudi Listed Government-Related Companies (LGRCs). Such a study will help to shed light on the need for fully privatized programs, the speed and pace of such programs and the effect of government presence in the corporate sector in Saudi Arabia.

Using data on publicly listed LPCs and LGRCs over the period 2000-2003, this study considers two specific questions:

1. Does the operating performance of the Saudi LPCs exceed that of the Saudi LGRCs?

2. Does the under-or out-performance, if any, translate into market performance for shareholders in the stock market.

The remainder of this paper is organized as follows. Section II reviews the literature on the performance of state - owned enterprises and private companies. The data and methodology are described in section III. Section IV presents the results and analysis and finally section $\mathrm{V}$ summarizes and concludes the study.

\section{LITERATURE REVIEW}

It has long been the conviction that public enterprises or government-administered organizations are more concerned with social, political and all but economic outcomes of business activities. In the Orient, especially in the Arab world, most of the managers of government-related corporations are mainly civil servants or retired military staffs who lack real business keenness and talents. Moreover, their investment and business decisions may be, to a large extent, politically, rather than commercially motivated. The less efficiency is due also to their investment relationship with the government, and the management systems applied within. What make matters worse is that these managers are generally too risk averse, and have no incentives to venture into risky but otherwise economically rewarding projects.

It is argued by many that this loss of efficiency is attributed in part to ownership effects. Boycko et al (1996) stated that politicians cause government-linked corporations (GLCs) to employ excess labor input. Further, as argued by Krueger (1990), the GLCs may be pressured to hire politically connected people rather than tapping the market for professionals, or just pursuing other than profit maximizing goal (Ramamutri, 1987). It is, however, argued by Jones (1991) that corporatizations can provide management of government owned enterprises with clear goals around which government policies must be formulated. A related reason usually put forward as a possible explanation for the less efficient performance by GLCs is the government rigid and bureaucratic supervision of these institutions (form not substance) (Chang and Singh 1997). Additionally, there is almost complete absence of incentives for managers to pursue efficiency and profitability for their institutions. Easy access to government cheap, guaranteed, or recommended financing may lower managers' drive towards efficient utilization of resources, and reduce threats of jobs loss, job advancement or even bankruptcy. However, state-owned enterprises in some countries performed poorly even after reforms were introduced (Christensen 1998).

Moreover, it may be argued that the principal - agent relationship of the type depicted in the work of Fama (1980) and Fama and Jensen (1983) is not as strict or as profit- oriented as in privately-owned companies. The objective in public or government linked companies is not to pursue profit maximization goals, but rather to ensure that rules and regulations are adhered to and followed even sometimes at the expenses of profitability. Vickers and Yarrow (1991) argue that privatization could improve performance of publicly-owned organizations and solve the agency problem and improve efficiency. 
These lines of arguments found some support in empirical studies in this area. For example, Ahuja and Majumdar (1998) examined the performance of 68 Indian state-owned enterprises in the manufacturing sector during the 1987-1991 period. The study found that state- owned enterprises were posting lower performance than their privately-owned counterparts. Similarly, Dewenter and Malatesta (2001) used a large data set for GLCs and non GLCs which are included in Fortune magazine's Global 500 for 1975, 1985, and 1995. Their results indicate that GLCs are significantly less profitable than privately-owned firms. Evidence for the inferior performance of GLCs can be traced also in array of studies that have been initially directed to examine the effect of privatization on corporate performance. For example, a recent study by Farinos et al (2007) found significant operating performance improvement in Spanish state-owned enterprises privatized through public share issue offerings during the 19902001 period.

On the other hand, GLCs out-performance has also found comparable empirical support in the literature. Some authors contend that GLCs are not always inherently less efficient than private corporations. Private firms may, at times, pose inferior efficiency output than government-owned ones. Among the cited reasons of possible inefficiency in private enterprises (non GLCs), is the inadequacy of corporate governance. Even bureaucracy may be a common factor in these situations (Chang and Singh 1997). Further arguments in defense of GLCs rest on the concentrated government ownership in GLCs. For example, Dewenter and Malatesta (1997) argue that the government, as a blockholder in GLCs, is in a better position to closely monitor the GLCs managers than dispersed owners in private corporations.

Some studies tried to seek conceptual examination of ownership structure outside the dual public-private ownership context. A study by McGuiness, et al (2005) considered two forms of ownership structure of Chineselisted companies. Mainly, the study examined the effects of state and foreign ownership on the listed Chinese corporations' performance. The study examined state-owned enterprises with substantial foreign ownership. The study found negative association between free-float size and corporate performance. Additionally, the study found that in spite of the sizable foreign ownership state, such stakes are not significantly associated with corporate performance.

The question of whether the financial market rewards or penalizes the state ownership is examined by Ramurez and Tan (2004) in a study that sampled government-linked corporations in Singapore that were run on a competitive commercial basis. The study found evidence that being a GLC is rewarded in financial markets with a positive premium over a normal Tabin's $Q$.

Some argue that government ownership represents an important signal to the market since it gives company credibility and also assures investors and markets, contractors, and suppliers because of the government readiness to insure transactions with these parties. A study by Bourdman \& Vining (1989) examined samples of three ownershipbased categories of companies: state-owned, privately-owned, and mixed-owned. The study found that, partial privatization, with the government retaining some equity ownership, was found a viable and a better strategy for a government that plans to move away from state ownership form. A study by Ang \& Ding (2006) compares the financial and market performance of GLCs and non GLCS in Singapore and found that the GLCs have better corporate governance and higher valuations compared to non GLCs. Omran (2004) also have shown that Egyptian privatized firms do not exhibit significant improvement in performance compared with state-linked corporations. Similar results, but for different reasons, were exhibited by studies in highly developed economies such as the one by Bozec (2003) in Canada and Kole and Mulherin (1997) in the United States. The U. S. study found that in the U.S., corporations where government owned an interest (between 35-100\%) showed performance not statistically different than that of private sector firms in the same industry. They attribute their results to the existence of similar monitoring mechanism in the government-owned corporations to that of private sector firms.

Similarly, a recent and more comprehensive study was conducted by Micco et al (2007) where it examined a large sample of commercial banks in 179 countries during the period 1995-2002. The objective of the study was to examine the relationship between bank ownership and performance and to test whether there is a political factor effect. State-owned banks operating in developing countries tend to have lower profitability, lower margins and higher overhead costs than their privately-owned counterparts. This relationship was weaker in the case of industrial countries. 


\section{DATA AND METHODOLOGY}

The data used in this study includes all private and state-related corporations listed on Saudi stock market, Tadawul, during the period 2000-2003. This study window is chosen for many reasons. First, before 2000, there was not much interest by the public in the ownership issue and in the corporate sector performance. The interest in corporate sector and the spread of corporate culture is a recent trend in the kingdom. However, the government showed enthusiasm for privatization and took practical steps by forming the Saudi Arabian General Investment Authority (SAGIA) in 2000, which spearheaded the privatization program in the kingdom. Earlier in August 1997, the Cabinet issued decree No. 60 that established the objectives of the privatization in Saudi Arabia, while decree No. 257, which was issued later in February 2001, assigned responsibility of the privatization program to the Supreme Economic Council, headed by the King. Second, the year 2004 witnessed the establishment of the Capital Market Authority (CMA), which was assigned the oversight of the Saudi stock market. Third, many companies were listed following the establishment of the CMA and they were relatively newly established or turned into public companies. Fourth, during 2000-2003 periods, the Saudi economy and stock market were stable, and there was almost no major structural change that may interfere with the primary analysis at hand.

Thus, we include all listed companies on the Saudi stock exchange, Tadawul, which are either 100\% privately owned or partially owned by government, since there is no listed company which is wholly owned by the government. The partially government-owned sample includes those companies in which the government owned small percentage that does not constitute an effective ownership. However, still these small shares are considered to be sizable and influential in management and control. This is due in part to the pattern of the shares ownership in Saudi Arabia. Most shares in the Saudi market are owned by individual shareholders (94-96 percent) who own small amounts of shares. Thus, sometimes a $1 \%$ share ownership in a company places the government as the largest shareholder and therefore entails significant control over the affairs of the company. Table 1 shows the government ownership in various economic and stock market sectors.

Table (1)

Government Ownership in Stock Market Sectors

\begin{tabular}{|c|c|c|c|c|}
\hline Economic Sector & $\begin{array}{c}\text { Total No. of } \\
\text { Companies }\end{array}$ & $\begin{array}{c}\text { No. of Companies } \\
\text { with govt. ownership }\end{array}$ & $\begin{array}{c}\text { Average } \\
\text { ownership (\%) }\end{array}$ & $\begin{array}{c}\text { Range } \\
\text { of ownership (\%) }\end{array}$ \\
\hline Banking & 11 & 9 & $13 \%$ & $0-29 \%$ \\
\hline Industrial & 25 & 6 & $20.2 \%$ & $0-70 \%$ \\
\hline Cement & 9 & 6 & $21.9 \%$ & $0-39.9 \%$ \\
\hline Services & 19 & 7 & $28.4 \%$ & $0-72.9 \%$ \\
\hline Agriculture & 9 & 3 & $20.8 \%$ & $0-40 \%$ \\
\hline Electricity & 1 & 1 & $74 \%$ & $74-74 \%$ \\
\hline Communications** & 1 & 1 & $70 \%$ & $70-70 \%$ \\
\hline Total & 75 & 33 & & \\
\hline
\end{tabular}

* Electricity listed companies were combined in one big listed company in 1999.

**Communication sector was dominated by government ownership, (Saudi Telecom Company) until 2000, where the government offered $30 \%$ of its shares to private ownership through a public offer.

The operating and market data for the variables chosen in this study, to measure the performance of the sampled private and government-related corporations comes from Tadawul website. It includes the audited financial statement and shares closing market prices of these companies. The study uses three indices to measure operating performance.

1. Operating efficiency surrogated by return on assets

2. Profitability which is defined in terms of return on equity and net profit margin

3. Productivity which is defined in term of Sales efficiency

On the other hand market performance is introduced through two measures. 
1. Stock Return which is defined as annual changes in shares prices

2. Risk which is defined in term of daily standard deviation of returns

Table (2) summarizes these measures and shows their definitions:

Table (2)

Measures of Performance and their definitions:

\begin{tabular}{|c|c|c|c|}
\hline & Indicator & Variable & Symbol \\
\hline \multirow{3}{*}{ Operating Performance } & Operating efficiency & Return on Assets & ROA \\
\cline { 2 - 4 } & Profitability & (i) Net Profit Margin & NPM \\
& & (ii) Return on Equity & ROE \\
\cline { 2 - 4 } & Productivity & Turnover (sales) per employee & TPE \\
\hline \multirow{2}{*}{ Market Performance } & Return & Annul stock return & RET \\
\cline { 2 - 4 } & Risk & Daily Standard Deviation of Returns & SD \\
\hline
\end{tabular}

These variables are calculated for each company included in the study over the four-year period. Although other measures of performance are legitimate candidates for use in this study, such as EVA or cost and expenditure efficiency indicators, a study by Eljelly \& Algurair (2001) has shown that EVA does not correlate well with stock prices in Saudi Arabia. Moreover, most studies tend to conclude that earnings and profits are significant measures of corporate performance. Besides their availability, they have high correlation with other performance measures such as cash flow measures of performance (see Eljelly \& Algurair 2001). The authors also showed that traditional (accounting-based) measures explained stocks price changes in Saudi Arabia.

On the other hand, Monczka and Morgan (2000) state that companies' managements find it easy and convenient to use the traditional indicators of company's performance such as ROA and measures of company stock performance. A study by Roztocki and Needy (1998) found that small companies rely on traditional measures of performance as primary indicators of their business performance.

It is clear from the table that the government ownership spread over all stock market (economic) sectors. The size of government ownership is highest in the electricity \& communication sectors where the government owns most of the shares of two companies that comprise the two sectors. Government ownership in some companies is very small, but still has strong influence as discussed previously.

\section{RESULTS AND ANALYSIS:}

Table (3) shows the results for the sample period (2000-2003) for all the companies listed on Tadawul.

Table (3)

Performance of LPCs and LGRCs

(2000-2003)

\begin{tabular}{|c|c|c|c|c|c|c|}
\hline Operating Performance & & LPCs & LGRCs & t-statitics & N & p \\
\hline Efficiency & ROA & 2.86 & 6.13 & 3.8 & 283 & $.000 *$ \\
Profitability & ROE & .0637 & .1097 & 3.38 & 283 & $.001^{*}$ \\
& NPM & .1368 & .2147 & 1.46 & 283 & .145 \\
Productivity & TPE & 1588 & 1013 & 1.56 & 244 & .12 \\
Market Performance & & & & & & \\
Annual Return & RET & .353 & .271 & 1.17 & 281 & .24 \\
Daily Standard Deviation & SDd & .038 & .032 & 2.94 & 281 & $.004 *$ \\
Annualized Standard Deviation & SDa & .647 & .55 & 2.94 & 281 & $.004^{*}$ \\
Coefficient of Variation & RARET & .546 & .493 & .593 & 281 & .554 \\
\hline
\end{tabular}

$\mathrm{SDa}=\mathrm{SDd} \times \sqrt{290}$

* Significant at all levels of significance 
Table (3) shows that LGRCS performed at least as good as the privately owned companies (LPCs) with respect to all measures of performance. They have higher and statistically significant Return on Assets Ratio (ROA) (efficiency), Return on Equity (ROE), and higher Net Profit Margin (NPM) (21.47\%) than LPCs (13.68\%) (Profitability). However, the private companies show higher productivity (sales/turnover by employee) than the government-related companies.

However, the LGRCs failed to translate these operating gains and efficiencies into stock market gains for investors. The annual return for holders of private company stocks are higher (35.3\%) than the partially-owned public corporations (27.1\%), although with associated higher annual standard deviation of $64.4 \%$ compared to 55\% for the government related companies.

The comparatively low stock market performance by the government related companies is due to the low trading activity. It is generally observed that stocks, in which the government owns a significant stake, have lower daily trading volumes and trading values. The reason for lower trading activity is due to the long-term investment nature of government ownership. This has eventually led Tadawul Company to introduce a free float index from which government ownership is excluded.

Table (4) shows the correlation coefficients between the various performance variables and the government ownership as well as among the performance variables themselves. The correlation coefficients in the first column as well as their level of significance indicate the presence of strong real relationship between the government ownership variable and all the operating and market performance measures. We also observe the high and significant correlations among the various performance measures.

Table (4)

Pearson Correlation Matrix

\begin{tabular}{|c|c|c|c|c|c|c|c|c|}
\hline & Gov. & ROA & ROE & PM & SD & RET & SECT & TPE \\
\hline ROA & $\begin{array}{l}.221 * \\
(.000)\end{array}$ & & & & & & & \\
\hline ROE & $\begin{array}{l}.198 * \\
(.001)\end{array}$ & $\begin{array}{l}.824^{*} \\
(.000)\end{array}$ & & & & & & \\
\hline PM & $\begin{array}{l}.087 \\
(.145)\end{array}$ & $\begin{array}{l}.435^{*} \\
(000)\end{array}$ & $\begin{array}{l}.499^{*} \\
(.000)\end{array}$ & & & & & \\
\hline SD & $\begin{array}{l}.173 * \\
(.004) \\
\end{array}$ & $\begin{array}{l}-.084 \\
(.161) \\
\end{array}$ & $\begin{array}{c}-.125^{* *} \\
(.037) \\
\end{array}$ & $\begin{array}{l}.093 \\
(.120) \\
\end{array}$ & & & & \\
\hline RET & $\begin{array}{l}-.069 \\
(.246) \\
\end{array}$ & $\begin{array}{c}-104 * * * \\
(.083)\end{array}$ & $\begin{array}{l}.041 \\
(.494)\end{array}$ & $\begin{array}{l}.001 \\
(.98)\end{array}$ & $\begin{array}{c}.153 * * \\
(.01)\end{array}$ & & & \\
\hline SECT & $\begin{array}{l}.179 * \\
(.003)\end{array}$ & $\begin{array}{c}.117 * * \\
(.05)\end{array}$ & $\begin{array}{l}-.362 * \\
(.000)\end{array}$ & $\begin{array}{l}-.287 * \\
(.000)\end{array}$ & $\begin{array}{l}.018 \\
(.77)\end{array}$ & $\begin{array}{c}.054 \\
(.365)\end{array}$ & & \\
\hline TPE & $\begin{array}{l}-10 \\
(.12)\end{array}$ & $\begin{array}{l}-.037 \\
(.565) \\
\end{array}$ & $\begin{array}{l}-.052 \\
(.420)\end{array}$ & $\begin{array}{l}-.041 \\
(.52)\end{array}$ & $\begin{array}{l}-.025 \\
(.702)\end{array}$ & $\begin{array}{l}.065 \\
(.315)\end{array}$ & $\begin{array}{l}-.082 \\
(.202)\end{array}$ & \\
\hline Log Asset & $\begin{array}{l}.381 * \\
(.000) \\
\end{array}$ & $\begin{array}{l}.100 \\
(.094) \\
\end{array}$ & $\begin{array}{l}.462 * \\
(.000) \\
\end{array}$ & $\begin{array}{l}.285^{*} \\
(.000) \\
\end{array}$ & $\begin{array}{l}.226^{*} \\
(.000) \\
\end{array}$ & $\begin{array}{l}.091 * \\
(.129) \\
\end{array}$ & $\begin{array}{l}.337 * \\
(.000) \\
\end{array}$ & $\begin{array}{l}-.008 \\
(.897) \\
\end{array}$ \\
\hline \multicolumn{9}{|c|}{$\begin{array}{l}\text { * significant at the } 1 \% \text { level } \\
\text { ** significant at the } 5 \% \text { level } \\
\text { *** significant at the } 10 \% \text { level } \\
\text { All symbols as defined before. In addition : } \\
\text { SECT: sector of the stock market } \\
\text { Log Asset: Logarithm of Company's total assets }\end{array}$} \\
\hline
\end{tabular}

The next step is to use pooled regression analysis to estimate the effect of ownership as well as other control variables on companies' performance. Thus, a regression model is specified in order to combine other independent variables that may affect the chosen measure of performance. The variables are percentage of government ownership (the magnitude of ownership) $(\mathrm{OWN})$ in the specific company, the sector or industry in 
which the company operates (SECT), and the size of the listed company (SIZE). Thus, the regression model takes the following form:

$\mathrm{PERF}_{\mathrm{it}}=\alpha+\mathrm{B}_{1} \mathrm{OWN}_{\mathrm{it}}+\mathrm{B}_{2} \mathrm{SIZE}_{\mathrm{it}}+\sum_{i=3}^{i=8} \beta i \sum_{j=1}^{j=6} S E C T j+\mathrm{e}_{\mathrm{i}}$

Where:

PERF $_{\mathrm{it}}=$ (i) Return on Assets (ROA)

(ii) Return on Equity (ROE)

(iii) Net Profit Margin (NPM)

(iv) Turnover per employee (TPE)

(v) Annual Return (RET)

(vi) Standard deviation of returns (SD)

$\mathrm{OWN}_{\mathrm{it}}=$ percentage of government ownership in the shares of company $\mathrm{i}$ at time $\mathrm{t}$

$\mathrm{SIZE}_{\mathrm{it}}=$ size of company $\mathrm{i}$ (as measured by log of total assets) at time $\mathrm{t}$.

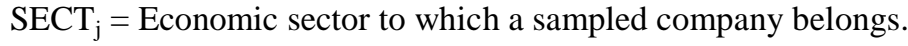

Table (5)

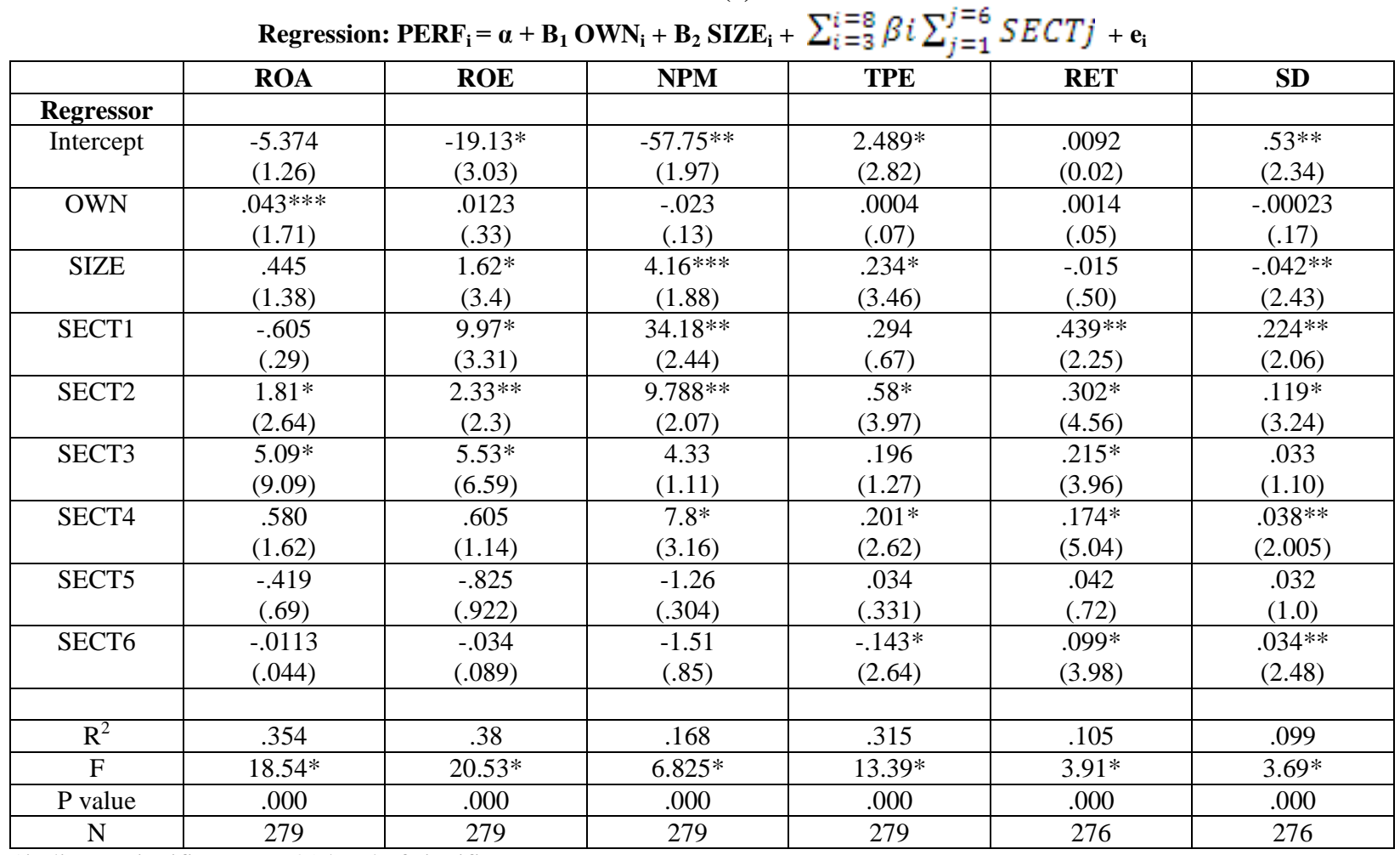

*indicates significance at .01 level of significance

** indicates significance at .05 level of significance

$* * *$ indicates significance at .10 level of significance

- $t$ values between parentheses.

The regression analysis indicates a significant positive relationship between most of profitability and efficiency measures and size. In the ROA regression, there were differences among various sectors (industries) with respect to their significance as determinants of variation in performance. However, the magnitude of government 
ownership has no significant effect on performance as measured by ROA, while the magnitude of government ownership has significant impact on ROA.

ROA, on the other hand, is significantly affected by the economic sector in which a company is operating, the size of the company, but not the magnitude of government ownership. The signs of the size coefficient is positive indicating an effect of economies of scale, while the sector coefficient sign is high and positive especially for SECT1 (the banking sector), which is plausible given the high profitability of the banking sector and the low capital provided by shareholders. For NPM and TPE the size effect is significant and positive indicating also economies of scale factor in performance. The economic sector coefficients show different signs and significance levels indicating varying performance among sectors.

For the market performance indicators, both return and risk vary widely between economic sectors. However, only risk varies significantly negatively with size indicating the lower risk of large (blue chip) companies relative to smaller ones. Both market performance variables are not affected by the magnitude of government ownership.

\section{SUMMARY AND CONCLUSION}

This study examines the relationship between form of corporate ownership and corporate performance among Saudi listed companies. The objective is to compare the operating and market performance of Listed Private Companies (LPCs) with Listed Government Related Companies (LGRCs).

The study finds that on average LGRCs significantly outperform LPCs with respect to profitability, and do better in efficiency measures, although the differences are not always significant. Correlation results show significant relations between the performance measures and government ownership. Pooled regression analysis shows that some measures of performance are affected by the size of the company, the magnitude of government ownership and the economic sector in which company operates. With respect to market performance, the two categories of ownership show comparable performance on risk adjusted basis.

The results of this study may shed light on the debate relating to the issue of complete or partial privatization of the still wholly owned government enterprises, and the best form of transfer or transition to use.

\section{NOTES}

The opinions expressed in this paper and the results obtained are that of the author and do not necessarily reflect the opinion of the Capital Market Authority (CMA) of Saudi Arabia.

\section{AUTHOR INFORMATION}

Dr Abuzar M. A. Eljelly, DBA (southern Illinois University at Carbondale, 1994); assistant professor of accounting and finance, University of Khartoum, Sudan, 1994-1997; associate professor of finance, King Saud University, Riyadh, 1997-2007; currently working as research advisor at Capital market Authority, Riyadh, Saudi Arabia.

\section{REFERENCES}

1. Ahuja, G. and Majumdar, S. K. 1998. "An assessment of the Performance of Indian state - Owned Enterprises” Journal of Productivity Analysis, 9 (2), pp. 113-132.

2. Aivazian, Varouj, A., Ying Ge, and Jiaping Qiu, 2005. "Can Corporatization Improve the Performance of State- Owned Enterprises Even Without Privatization?” Journal of Corporate Finance, 11, pp. 791-808.

3. Al-Barrak, Abdulrahman, O., and Mohammed A. Al- Harran, 2007. "The Debated Relationship between Privatization and Efficiency in Saudi Public Enterprises". KSU Scientific Depository, 17 (1).

4. Al-Sarhan, Mohammed and John, R. Presley, 2001. "Privatization in Saudi Arabia: An Attitudinal Survey". Managerial Finance, 27(10/11), pp. 114-122. 
5. Ang, J. S. and Ding, D. K., 2006. "Government Ownership and the performance of Government-Linked Companies: The Case of Singapore”. Journal of Multinational Financial Management, 16, pp. 64-88.

6. Boycko, M., Shleifer A., Vishny, R.W., 1996. “A Theory of Privatization”. Economic Journal, 106, pp.309-319.

7. Bozec, Richard, 2003. "Corporatization Process and the Financial Performance of Canadian state- Owned Enterprises”. The International Journal of Public Sector Management, 16, pp. 27-47.

8. Bubakri, N. and Cosset, J. C. 1998. "The Financial and Operating Performance of New Privatized Firms: Evidence from Developing Countries". The Journal of Finance, LIII (3), pp. 1082-1110.

9. Bourdman, Anthony, E., and Aidan R. Vining, 1989, "Ownership and Performance in Competitive Environment: A Comparison of the Performance of Private, Mixed and State-Owned Enterprises". Journal of Law and Economics, 32 (1), pp. 1-33.

10. Chang, H. and A. Singh ,1997. "Policy Arena: Can Large Firms be Run Efficiently Without Being Bureaucratic?", Journal of International Development, 9 (6), pp. 865-875.

11. Christensen, Peter F., 1998. "Performance and Divestment of State - Owned Enterprises in Ghana". Public Administration and Development, 18, pp. 281-293.

12. Dawley, David and Haidar, Jamal Ibrahim, 2008. "Privatization and Financial Performance: Can Value be Created by Privatizing State-Owned Enterprises in the Middle East and North Africa (MENA) Region?". Journal of Business Valuation and Economic Loss Analysis, 3 (1).

13. Dewenter, K. L. and Malatesta, P. H. 2001. "State - Owned and Privately Owned Firms: An Empirical Analysis of Profitability, Leverage, and Labor Intensity”. American Economic Review, 91 (1), pp. 320-334.

14. Eljelly, Abuzar M.A., and Algurair Khalid, S., 2001. "Performance Measures and Wealth Creation in an Emerging Market: The Case of Saudi Arabia”. International Journal of Commerce and management, 11 (3), pp. 54-72.

15. Fama, E. and M.C. Jensen, 1983. "Separation of Ownership and Control." Journal of Law and Economics, 26 (2), pp. 301-326.

16. Fama, E. 1980." Agency Problems and the Theory of the Firm” Journal of Political Economy, 88 (2 ), pp.288-307.

17. Farinos, Jose E., C. Jose Garcia, and Ibanez, Ana Ma., 2007. Operating and Stock Market Performance of State-Owned Enterprise Privatization. International Review of Financial Analysis, Vol 16, 4, pp.367.

18. Himmelberg, C., R. Hubbard and D. Palia, 1999. "Understanding the Determinants of Managerial Ownership and Link Between Ownership and Performance" Journal of Financial Economics, 53:,pp. 353384.

19. Jones, L. P. 1991. "Performance Evaluation for Public Enterprises". World Bank Discussion papers, No. 122.

20. Kole, Stacy, R. and Harold J. Mulherin ,1997. "The Government as a Shareholder: A case from the United States". The Journal of Law and Economics, 40.

21. Krueger, A., O., 1990. "Government Failure in Development”. Journal of Economic Perspectives, 4(3), pp. 9-23.

22. McGuiness, Paul B., and Michael J. Ferguson, 2005. "The Ownership Structure of Listed Chinese StateOwned Enterprises and its Relation to Corporate Performance". Applied Financial Economics, 15 (4), pp. 231-246.

23. Mckinlay, Peter. 1988. "State-Owned Enterprises and Crown Companies in New Zealand". Public Administration and Development, 18, pp. 229-242.

24. Micco, Alejandro, Ugo Panizza and Monica Yanez, 2007. "Bank Ownership and Performance: Does Politics Matter". Journal of Banking and Finance, 31, pp. 219-241.

25. Monczka, Robert M. and James P. Morgan, 2000. "Why Economic Value Added needs to be measured". Purchasing, 129 (2), pp. 77.

26. Omran, M., 2004. "The Performance of State-Owned Enterprises and Newly Privatized Firms: Does Privatization really matters". World Development, 32 (6), pp. 1019-1041.

27. Ramamutri, Ravi 1987. "Performance Evaluation of State-Owned Enterprises in Theory and Practice. Management Science, 33 (7), pp. 876-893.

28. Ramurez, Carlos, D., and Ling Hui Tan 2004. "Singapore Inc. Versus the Private Sector: Are Government - Linked Companies Different?” IMF Staff Papers, 15 (3), pp. 510-519. 
29. Vickers, J. and Yarrow, G., 1991. “Economic Perspectives on Privatization”. Journal of Economic Perspectives, 5(2) pp. 111-132.

30. Wei, Z., Varela, O., Hassan, M., K. and d'souza, J., 2003. "The Financial and Operating Performance of China's Newly Privatized Firms”. Financial Management, 32, pp. 107-126.

\section{NOTES}

